\title{
Comparative Analysis of the Effects of Organization Development Interventions on Organizational Leadership and Management Practice: A Case Of Green Earth Program (GEP)
}

\author{
David Minja
}

\begin{abstract}
This study was an analytical descriptive research done to assess the effects of organization development interventions on leadership and management practises of Green Earth Program.

The theoretical framework was based on the models developed by Kotter and Lippit and the conceptual framework was based on the effects of organization development interventions framework of leading change.

A pre- assessment of leadership and management practice at Green Earth was conducted which identified six problem areas or improvement issues. These were: absence of a strong compelling vision and an organization structure that encouraged an unhealthy competitive conflict, failure to involve staff at all levels in decision making especially in areas affecting their work, inadequate information flow (communication), a perceived unfair reward system and lack of human resources management policies and procedures, weak financial accountability practice and lack of financial management policies and procedures.

The data from pre- assessment and post assessment were statistically treated using the means. A t-test was also used for the comparison of the pre and post interventions data, for improvements significance at 0.05 alpha levels. The results of the pre and post intervention assessments showed that the effects of the interventions was statistically significant.

The study findings revealed that the overall mean for pre- assessment was 1.45 while the overall mean for post intervention assessment was 1.81 . The overall $p$ value was $p=0.000$. This was a clear indication that there was a very significant difference between data obtained during pre- assessment and data obtained after post intervention assessment.

The above results led to the conclusion that the Organization Development Interventions offered were successful since there was a significant difference in the data before and after the interventions. These results therefore, led to the rejection of the hypothesis which stated that there were no significant differences in the obtained data on the six problems areas before and after the interventions. This hypothesis was to be accepted or rejected at the 0.05 alpha level.
\end{abstract}

Key words: organization development Interventions, Organizational leadership, Financial Accountability 


\section{Introduction}

Corporate transformation has helped organizations that have lost their way and greatly depleted their resources transform themselves for competitive excellence. Many organizations performing poorly have had a chance to restore financial viability, pursue quantum revenue growth and successfully integrate merged operations. On the other hand, organizations at the top of the corporate game have been helped through corporate transformation to sidestep complacency and energize their people to redirect their efforts and reinvent themselves (Miles, 1997).

According to Mohrman, Galbraith, Lawler III (1998), change, change and still more change seems to be the agenda for the successful organizations of the future. These authors argue that the ultimate organizational capability, particularly in a complex organization, may be change management. Success will depend on constant alteration of organizational structures, reward systems, skills, information systems and business strategies. Change at the top will also be expected to take place. Corporate boards are assigned a critical role in the governance of corporations. Higher performance demands placed on corporations today have increasingly led to a greater focus on board effectiveness. These have led organizations to change the way they operate.

Green Earth Program, hereinafter referred to as GEP, is a grassroots wildlife conservation Non Governmental Organization(NGO) made up of registered members drawn from all sectors of the Kenyan society with an emphasis on greater youth involvement. GEP was launched in 1998 and is duly registered under the provisions of the Non-Governmental Organizations Act, 1990 section 3(10) of Laws of Kenya as an independent body.

The initial assessment that prompted the need for change revealed challenges in the following six areas: compelling strategic vision, Organizational Structure, communication, decisionmaking, reward system, and financial accountability. It is because of these challenges that made change (transformation) of Green earth program absolutely necessary. Therefore, this case study is on the implementation of corporate transformation at GEP. The purpose of this study was to conduct a comparative analysis of the effects of Organization Development Interventions on organizational leadership and management practices at Green Earth Program after the implementation of the interventions.

\section{Challenges at GEP}

\section{Compelling Strategic Vision}

First, the organization did not have a compelling strategic vision that could provide a framework for mission, goals, participation and communication. The genius of organisational leadership is to have a well- defined direction and vision which is simple but well articulated. Almond, (200)5, Miles (1997) argue that successful corporate transformations share a fundamental attribute- vision. Transformational change requires a projection into a dimly lit 
future. By necessity, then, visionary leadership is the essence of successful corporate transformation.

This meant that the organisation needed to undergo a major transformation. Mohrman, Galbraith, Lawler III (1998), argue that strategizing enables an organization to fit- in with the changing business environment and be at the cutting edge of competition. As Harigopal (2006) has observed, transformational change involves the entire or a greater part of the organisation. This calls for a revolutionary mindset, envisioning, energizing and an enabling change agent(s). Bogler and Adam, (2001), however, caution that vision should never be used as a manipulative tool but a managerial one.

\section{Organizational Structure}

Second, the Organizational Structure was a source of competitive conflict among the top management. At the top of the hierarchy were two boards on the same level: Board of Trustees and Board of management. Hill and Jones (1998) have proposed that an organization should create a structure that will allow it to pursue its strategy most effectively. Such structures plays the roles of coordinating the activities of employees effectively so that they work together most effectively to implement a strategy; and motivates employees and provide them with the incentives to achieve superior efficiency, quality, innovation or customer responsiveness. As Harigopal (2006) has further observed, change entails linking strategy, structure, people, process and culture, with a purpose.

Shapiro, (1991), Harigopal,(2006) argue that appropriate structures enable organizations to stay focused, be more nimble and speedy in its operations. Initial assessment revealed that the original set of arrangement in Green Earth Program was hindering effective deployment of organizational resources to achieve strategic goals. Effective deployment of resources is reflected in the organization's division of labour into specific departments and jobs, formal lines of authority, and mechanisms for coordinating diverse organization tasks (Daft, Samson 2005). In view of this fact, GEP had to create the right kind of organizational structure that could effectively facilitate the flow of resources, information and capabilities within the organization.

In the case of GEP, formal lines of authority were not clear especially at board level because two equally powerful boards operated on the same level. There was therefore no clear chain of command. Higher performance demands placed on today's corporate boards have increasingly led to a greater focus on board effectiveness. The organization could not afford to stay the same because the two boards were hampering operations and making the organization ineffective.

\section{Communication}

Thirdly, information was not being effectively shared from top to bottom. Though downward communication is the most familiar and obvious flow of formal communication in many organisations, this was not the case with GEP. At times, employees down the hierarchy did not even know the direction the organization was taking which made it difficult for lower cadre employees to buy-in the management's vision.

Effective communication is critical because it improves the implementation of goals and strategies. According to Seltzer and Bass, (1990), communication is key in any transformation effort. Leaders must succeed in raising colleagues, subordinates, followers, 
clients or constituencies to a greater awareness about the issues of consequence. They bring about change, innovation and entrepreneurship. They focus on the process of corporate transformations that recognize the need for revitalization, create a vision and institutionalize change. Avolio, Howell and Sosik, (1999), observe that transformational leaders build confidence in followers, encouraging them to reframe the future and question the tried and true, and coaching them to develop their full capabilities. All this requires effective information flow mechanism. Lerner (1952), observes that universal theory of communication suggests a causal relationship between communication and change, spread of new ideas, customs and practices which are a fundamental requirement for change to take place. Kearl (1986) has noted that communication is the premier agent, the means and the technology for accelerating the rate of transformation. Harigopal ( 2006) further argues that change mechanism involves the explaining of nature and direction of change, effective communication, creating a common value orientation and employee training. Baird (1977), argues that people want feedback and the type of feedback they receive affect subsequent performances. It is therefore not enough for employees to receive feedback but they must receive the best feedback possible. This feedback must have three qualities: clear, appropriate and positive, argues Baird.

Furthermore, feedback accelerates organizational learning during the transformation process. Senge (1990) observes that in this world of constant change, the only sustainable competitive advantage is an organization's capacity to learn. Efficient flow of information facilitates this process.

A study by Kirkpatrick and Locke(1996) found that the content of charismatic communication style(vision and task cues) led to higher performance quality and quantity. Leaders' articulation of vision emphasizing quality improved the attitudes and perception of followers and articulation of the task cues increased follower's task clarity and intellectual stimulation. As it has been observed by Bhargava (2003) these scholars concluded that vision and vision communication have positive effects on organization- level performances.

\section{Decision-Making}

Fourth, decision-making was not pushed down to the lowest possible level at which competent decisions could be made. Top executives make all the decisions. Even when it was more appropriate for employees and members of GEP to contribute to decision-making process, this did not happen. O'Toole(1996) argues that leadership requires inclusion of followers. This means that followers must fully participate in making decisions that both affect their work and the direction the organization is taking. Inclusive leaders enable others to lead by sharing information, by fostering a sense of community and by creating a consistent system of rewards, values, structure process and communication.

Lawler, (1986) argues that effective leadership emphasizes the need for employee involvement in decision making. Under certain conditions, employees are more committed to decisions and better decisions are made if they are involved. The most important overall emphasis in the work on employee involvement concerns locating decisions at the lowest level in the organization. A bottom- up approach to management is consistently advocated. Mohrman et al, (1998) further argue that individuals or teams should be given the power, information and knowledge that they need to work autonomously or independently of dayto- day managerial control and direction. 


\section{Reward System}

Fifth, reward system was seen to be unfair. This was attributed to lack of personnel policies. Bellhumeur (1999) observes that human resources are the core of the organization. They are engine that drives the organization entity and they are the foundation on which everything exists. This underscores the need for the organization to design reward systems that are perceived to promote equity in the organization.

The initial assessment revealed that management did not strive to maintain a sense of fairness and equity within the reward system. There was a great need for the organization to develop a pay structure thereby fortifying employee morale. There was Also a need to design and use a merit pay system rather than a system that was not based on any criterion.

Lawler and Jenkins, (1992) argue that the pay system is a critical part of any organization's design. Furthermore, pay systems that fit organization's strategies and structures have an important impact on how effective the organization is and on the quality of life that people experience in the organization.

Lawler, (1971) submits that reward systems in combination with other features of the organization's design, drives the performance of the organization because it influences critical individual and organizational behaviours. Therefore, they must be designed to support the needed organizational behaviours.

\section{Financial Accountability}

Sixth, financial accountability practice was perceived by employees as weak. One that encouraged lack of transparency. Kaplan, Norton ( 2001) argue that financial measure that foster accountability need to be proactively pursued in order to focus organizations for competitive success. Verschool (1995) argues that corporate values and focus on ethics( which are part of good financial accountability practice) do in fact result in superior financial returns. Good financial accountability brings greater success to the bottom line (financial performance).

The initial assessment indicated that there was need for GEP to enhance its financial accountability practice through formulation of policies and procedures to guide the process. Adherence to these policies and procedures would enhance financial accountability practice. The need for change in GEP was great as is the case with many other organizations in the world today. Mohrman, Mohrman (1997) argue that many organizations are changing to become dramatically more responsive to customers, efficient, fast and flexible.

Effecting transformation at Green Earth Program in the five identified areas was meant to increase organization's efficiency and make it more flexible in addressing the challenges that arise from the organization's dynamic environment.

\section{THEORETICAL FRAMEWORK Change Management Theories Definition of change management}

Change management is both a Science and an Art. It is a Science because it is an intellectual activity which involves theories and models. It is also an Art because it involves 'the getting people side of things right'. 
The first and most obvious definition of "change management" is that the term refers to the task of managing change (Burnes, 2000). Managing change is itself a term that has at least two meanings (Smith, 2001). One meaning of managing change refers to the making of changes in a planned and managed or systematic fashion. This definition focuses on effectively implementing new methods and systems in an ongoing organization. The second definition of change is "an area of professional practice". There are many consultants who proclaim that they are engaged in planned change, are change agents and that they are involved in change management practices. Most of the major management consulting firms have a change management practice interest (Burnes, 2000).

Managing change is both about readjusting to current changing situations and also about changing organizations so they can cope with change in the future. This means that you may be planning to accommodate specific change or planning to reshape the whole organization.

\section{Determining the need for change}

As noted by Carnall (2003), there are three pointers that determine the need for change in an organisation; recognising that a gap exists between the desired and actual performance, analysing the organisation's current competitive position (SWOT analysis), and determining the strategic changes necessary to achieve the desired future state for the company.

\section{Organization development (OD) approach to change management}

Organization development (OD) is often defined as a planned, top-down, organization-wide effort to increase the organization's effectiveness and health. According to Bennis (1969), OD is a complex strategy intended to change the beliefs, attitudes, values, and structure of organizations so that they can better adapt to new technologies, markets, and challenges. OD is neither "anything done to better an organization" nor is it "the training function of the organization"; it is a particular kind of change process designed to bring about a particular kind of end result. OD can involve interventions in the organization's "processes," using behavioral science knowledge as well as organizational reflection, system improvement, planning, and self-analysis.

Kurt Lewin (1898 - 1947) is widely recognized as the founding father of OD, although he died before the concept became current in the mid-1950s. From Lewin came the ideas of group dynamics, and action research which underpin the basic OD process which was applied in this study.

\section{Kotter's Model}

The theory guiding this study was Kotter's model of initiating and leading change in an organization. This model postulates that effective and lasting organizational transformation goes through eight phases which are: establishing a sense of urgency, creating a guiding coalition, developing a vision and a strategy, communicating the vision, empowering for broad-based action, generating short-term wins, consolidating gains and creating more change and anchoring new approaches in the culture( Kotter, 1996). Kotter argues that the rate of change in the business world is not going to slow down anytime soon. Competition in most industries will probably speed up over the next few decades. Enterprises will be presented with more challenges and wonderful opportunities as a result of globalisation of the economy along with related technological and social trends. Powerful macroeconomic forces 
may grow even stronger over the next few decades. As a result, more and more organizations will be pushed to reduce costs, improve the quality of products and services, locate new opportunities for growth, and increase productivity. The figure below shows the process of initiating successful change according to this model.

\section{FIGURE 1: Kotter's Model- Process of Creating Major Change}

\section{Establishing a Sense of Urgency}

Examining the market and competitive realities

Identifying and discussing crises, potential crises, or major opportunities

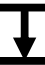

\section{Creating the Guiding Coalition}

Putting together a group with enough power to lead the change.

Getting the group to work together like a team.

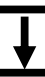

\section{Developing a Vision and Strategy}

Creating a vision to help direct the change effort.

Developing strategies for achieving that vision.

\section{Communicating the change vision}

Using every vehicle possible to constantly communicate the new vision and strategies

Havino the ouidino coalition role model the hohavinur ovnerted of omnloveac

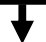

\section{Empowering for Broad-Based Action}

Getting rid of obstacles

Changing systems or structure that undermine the change vision

Fnenuraoino riclz takino and non-traditinnal ideac artivitioc and artinne

\section{Generating Short-Term Wins}

Planning for visible improvements in performance, or "wins"

Creating those wins

Visibly recognizing and rewarding people who made the wins possible.

\section{$\checkmark$}

\section{Consolidating Gains and Producing More Change}

Using increased credibility to change all systems, structures, and policies that don't fit together and don't fit the transformation vision.

Hiring, promotion, and developing people who can implement the change vision.

Reinvigorating the nrocess with new nroiects. themes and change agents

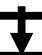

Anchoring New Approaches in the Culture

Articulating the connections between new behaviours and organizational success.

Develobing means to ensure leadership development and succession. 
SOURCE: Adopted from John P. Kotter, “Why Transformation Efforts Fail”, Harvard Business Review (March-April 1995)

According to Miles, (1997), the impetus for change need not be a crisis. Indeed, reliance on crisis to create readiness for change is an abdication of leadership responsibility. Instead, transformational leaders create incentives for people to change and be involved in the searchand - adaptation process, and expose them to models of the future toward which they will want to move.

\section{Lippit, Watson\& Westley Model}

Lippit, Watson, Westley (1958) change model and later modified by Kolb and Frohman (1970) demonstrate how planned change can take place in organisations. Their model of planned change is based on the principle that information must be freely and openly shared between the organisation and the change agent and this information must be able to be translated into action.

Just like Kotter who has developed a multi- stage model, Lippit, Watson and Westley (1958) developed a seven- step process. This process involves:

(i) Scouting- this is the stage that involves exploring the areas that require to be changed.

(ii)Entry- this involves the development of mutual expectations between the facilitator (change agent) and the organisation needing change.

(iii)Diagnosis- this stage involves identification of improvement issues and the goals to be achieved in the transformation initiative.

(iv)Planning- this stage involves identifying resistance to change and coming up with strategies to deal with the resistance.

(v)Action - this stage involves implementation of the transformation initiative plan of action.

(vi)Evaluation - this stage involves determining the extent to which the transformation initiative has been successful.

(vii)Termination - this stage involves the decision by the transformation agent on leaving the system that has been going through the transformation initiative.

Many change efforts have helped some organizations adapt significantly to shifting conditions, have improved the competitive standing of others, and have positioned a few for a far better future. Miles, (1997) submits that an organization undergoing transformation must adopt a total system approach. This approach must focus on vision, strategies, infrastructure, culture, competencies, people and structure. This approach seeks to boldly move an organization from an initial state to a vision state, not piecemeal, but by simultaneously articulating all the major elements of the whole organization. The typical twentieth-century organization did not operate well in a rapidly changing environment. Structure, systems, practices and culture were often more of a drag on change than a facilitator. With environmental volatility on the increase, the standard organization of the twentieth century will likely become a dinosaur ( Kotter, 1996).

Bennett (1962) identified four kinds of change that confront leaders. The first is change in structure. This has to do with the changing of the organizational chart, the shuffling of positions in personnel, and the reworking of the organization itself. Such a reorganization of a 
company or a committee is intended to change the relationship persons so that work is done more effectively and efficiently.The second kind of change comes in technology. The introduction of electronic process-e-mail, Internet, telemarketing can be classed as technological change.

The third type has to do with the behaviour of people. People must be helped in the present to develop behaviour which will enable them to be more effective and creative persons. This line of thinking is further supported by Lerner, (1952). He argues that transformation that focuses on people must stress the concept and skill of empathy. This skill has the capacity to see oneself in the other fellow's situation. It has the ability to project oneself into the role of another. He argues that those with high empathic skills and ability are the ones who will experience and effectively facilitate transformation initiatives.

The fourth type deals with assumptions and values. People's assumptions and values determine their behaviour; so leaders must understand why people behave as they do before they can help them change. Bennett (1962) says that the leader needs real insight into the assumptions and values guiding his behaviour, and why he has made his judgements about the importance of the change he is seeking. Even when assumptions and values are favourable to transformation efforts, Anderson (1995), argues that in most organisations, resistance to change may be woven into the fabric of corporate culture. This calls for the transformation agent to align corporate culture with change initiatives. Duck, (1993) observes that organization change is a difficult and frustrating issue virtually in every organisation. To deal with organizational resistance, he suggests that transformation agents should focus on organizational inertia and mediocrity.

As Thompson, (1997) has observed, policies are necessary and appropriate for guiding and directing decision making. The vision, mission and strategic objectives of the organization also need to be reviewed Zaleznik, (1996) further observes that efforts should start with changing people more than changing things

Zaleznik, (1996) further observes that the act of choice, whether through conscious or unconscious mechanisms, places the individual in the forefront of organizational behaviour. In the final analysis, people think, feel, choose, and act. In any organization desiring to effect change, the emphasis on changing people ought to be basic. Organizations must focus on changing the attitudes and behaviour of their employees. Any change is positive within an organization; but on the human level, leaders must operate within their own span of control and must be able to make reliable predictions about the consequences of their actions.

In regard to this, Bennett( 1962) says;

For most of us, this point is within day-by-day relationship in which we function. In these daily relationships with superiors, colleagues, and subordinates, a leader is likely to know more accurately what can be expected of other persons and what is expected of him.

When leaders develop and hand down a report of what they want to see changed, the change becomes more difficult to implement than when the people themselves or at least their representatives have a voice in planning the change. Involvement in the planning process tends to generate the necessary force for the change itself. Facts personally researched are better understood, more emotionally acceptable, and more likely to be utilised than those 
passed down by someone else. Participation in analysis and planning helps overcome resistance, which arises from proceeding too rapidly or too slowly(Miles,1997; Kotter,1996).

Zaleznik, (1996), argues that any leader who proposes change implies that the organization is not functioning satisfactorily. At that point some people become uncomfortable. Vested interest and/or conflict of interest are detriment to the process of change. As Harigopal, (2006) has observed, the importance of sustaining the momentum of the change effort to ensure the completion of the change initiative is without question. This demands maintaining the energy and interests of employees. People feel threatened by the thought of innovation in something of which they have long been apart. People, who have clear-cut involvement in what is changing, should make up the participants in the change process because their lives have been directly affected.

Kotter(1996) argues that successful change efforts reveal two important patterns. First, useful change tends to be associated with a multi-step process that creates power and motivation sufficient to overwhelm all the sources of inertia. Second, this process is never employed effectively unless high-quality leadership, not just excellent management, drives it. To be effective, Kotter argues that a method designed to alter strategies, reengineer processes, or improve quality must address these barriers and address them well. To produce successful change of any magnitude in organizations, the process must go through the eight stages and errors associated with these stages that undermine transformation efforts must be addressed.

To achieve fundamental change without exposing the organization to unacceptable risks, Miles(1997) submits the following:

The first and very fundamental step in planning a corporate transformation involves assessing the initial change condition. This initial condition may be described along two dimensions: readiness and resources.

The initial condition of corporate transformation ranges from a state of high readiness but low resources to a state of low readiness but high resources. Readiness is the extent to which employees recognize the need for change or, conversely, the extent to which they are dissatisfied with the status quo. The extent to which the organisation has the ability to support a transformation process is seen in its resources.

The opposite of the above condition is the low-readiness, high-resources situation. As a result of successful past performance, these companies have accumulated a surplus of resources. However, their people have become satisfied with current performance and are not actively searching for new and different ways of doing things. Readiness for change is very low. The order of the day is to extend and refine business as usual. These organisations are susceptible to the so-called paradox of success. Ultimate failure is associated with current success because the latter blindfolds the organization to new developments in the competitive environment that can ultimately overtake the company. Two poignant examples of colossal failures, formerly highly successful companies in the low-readiness, highresources condition, are General Motors in the automotive industry and IBM in the information-processing industry during the 1980's, Miles observes.

In the low-readiness, high-resources condition, the paramount need in launching transformation efforts is to legitimately elevate the level of dissatisfaction with the status quo. Effective transformational leaders in this condition must confront organisational 
members with data and experiences that catalyze the readiness for change. This underscores the importance of stage one in the eight stages of Kotter's model explained later in this chapter. This entails most if not all elements of the organizational system. It is deep change in that it affects people's beliefs, values and understandings.

As Miles,(1997)has argued, successful corporate transformations share a fundamental attribute: visionary leadership which is the very essence of successful corporate transformation. This is the reason why the researcher is focusing this study on strategic leadership practice of GEP. He has further observed that a primary goal of the approach to corporate transformation is to create a process architecture that enables companies to move into and remain in a high- readiness, high- resources model.

The initial change condition of a corporation imparts a bias at the launch of any corporate transformation. Transformational leaders in the high- readiness, low- resources condition need to focus a lot of initial attention on creating resources to initiate and sustain a transformation effort. Those in low- readiness, high- resources organizations will need to tilt the initial focus toward elevating the general level of dissatisfaction with the status quo.

In sum, the change of focus, the impetus for change need not be a crisis as pointed earlier. Indeed, reliance on crisis (performance shortfall, arrival of a new market entrant, obsolescence of a product line etc) to create readiness for change is an abdication of leadership responsibility. Instead, transformational leaders create incentives for people to engage in the search- and- adaptation process and expose them to models of the future toward which they will want to move.

\section{Conceptual Framework}

The conceptual framework was based on an action research five phase cyclical process to determine the changes in the following six areas: compelling strategic vision and unhealthy competitive conflict; information flow; decision making; reward system and financial accountability practice.

Figure 2: Conceptual; framework 


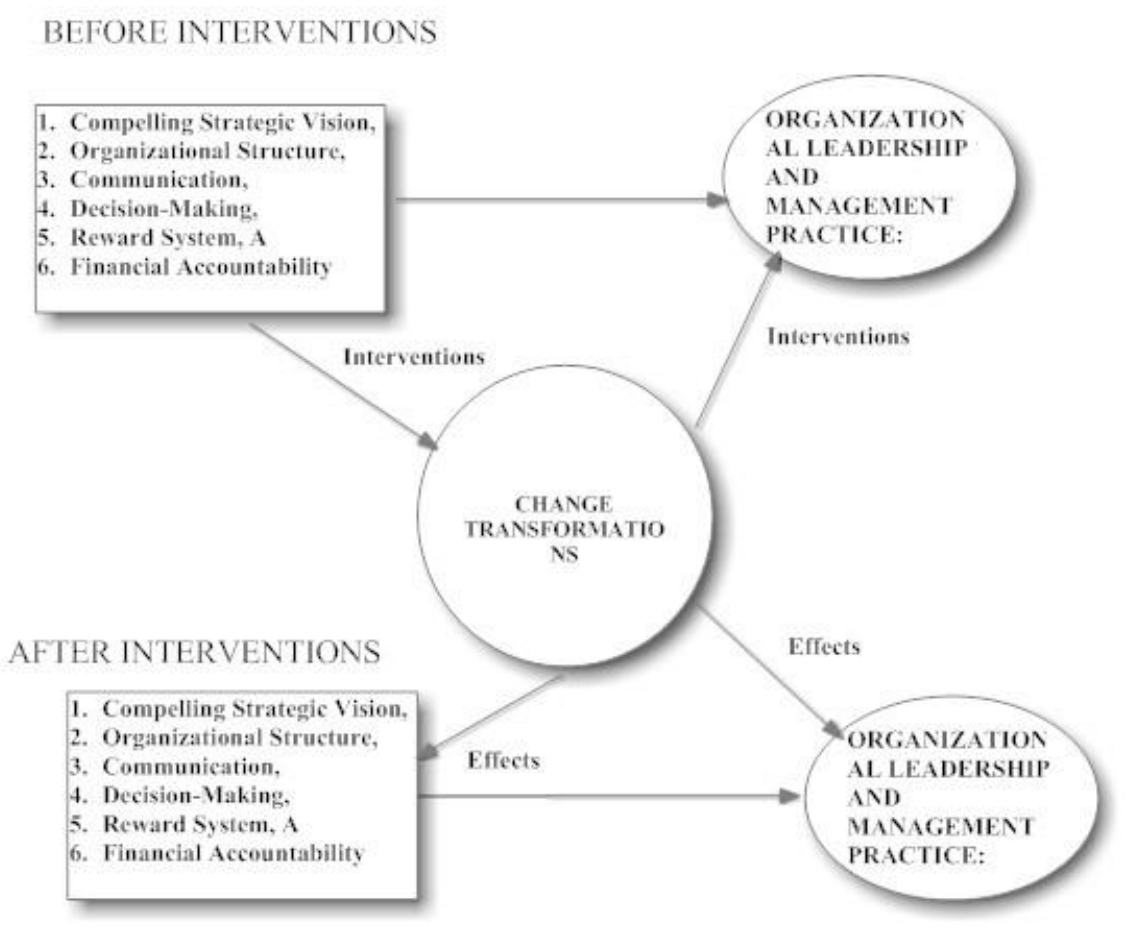

The above model postulates that organization development interventions administered would transform the six areas identified as needing improvement.During pre-interventions assessment, it was found out that the organization did not have a compelling strategic vision that provides a framework for mission, goals, participation and communication. The genius of organisational leadership is to have a well- defined direction and vision which is simple but well articulated. Almond, (200)5, The Organizational Structure was a source of competitive conflict among the top management. At the top of the hierarchy were two boards on the same level: Board of Trustees and Board of management.Information was not being effectively shared from top to bottom.

Though downward communication is the most familiar and obvious flow of formal communication in many organisations, this was not the case with GEP. At times, employees down the hierarchy did not even know the direction the organization was taking which made it difficult for lower cadre employees to buy-in the management's vision.Decision-making was not pushed down to the lowest possible level at which competent decisions could be made. Top executives make all the decisions. Even when it was more appropriate for employees and members of GEP to contribute to decision-making process, this did not happen.reward system was seen to be unfair. This was attributed to lack of personnel policies.Financial accountability practice was perceived by employees as weak. One that encouraged lack of transparency.

\section{Null Hypothesis}

There were no significant differences in the obtained data on the five problems areas before and after the interventions. This hypothesis was to be accepted or rejected at the 0.05 alpha level. 


\section{Schema of the Study}

\section{Figure 3: The Action Research Cycle}

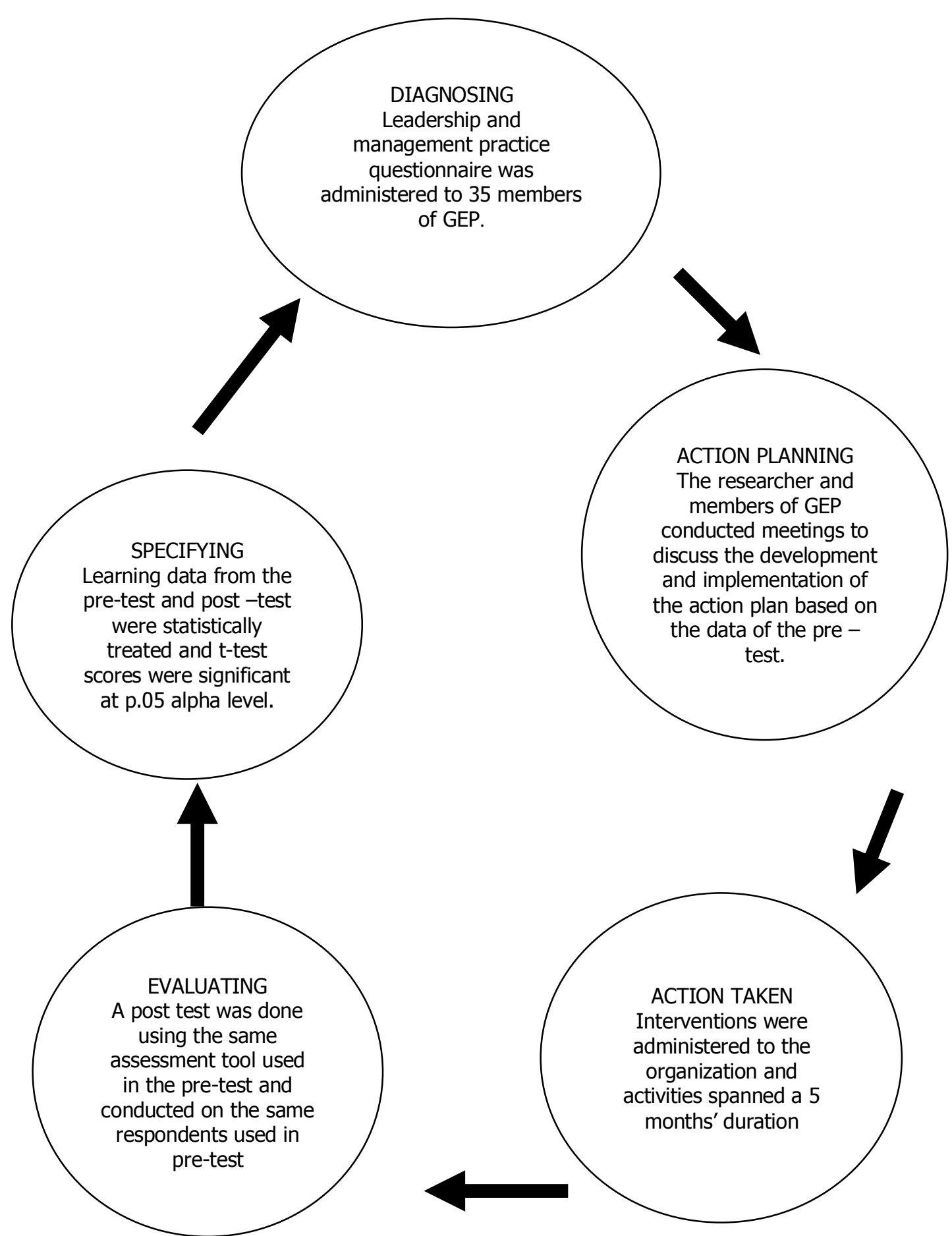

The interventions focused on: re-organization and capacity building. Elements of this process included the following: revising the organizational structure; planning and visioning, communicating the vision, creating/building a guiding coalition to lead change and 
empowering everyone in the organization to participate effectively in the change initiative. ODI conducted were:

i. Team building - this strategy was used to address the unhealthy organisational conflict by building a cohesive team.

ii. Planning and visioning- this strategy was used to help the organization improve on its strategic visioning and governance practice.

iii. Focus group discussions - this strategy helped members bring out issues that were of key concern to them.

iv. Participants were also encouraged to offer suggestions on how to address those issues. This gave employees an opportunity to participate in decision making.

v. Meetings - meetings were held to provide fora for information sharing and team building

vi. Training programs were designed to help organization's management and staff with knowledge on how to formulate financial and human resources management policies and procedures.

The above interventions provided a framework for the formulation of the schema of study given above.

\section{The research design}

\section{Method Used}

This study used two methods. The first was the assessment and evaluation of the five problems before and after intervention. The second was the descriptive research which compared the data before and after evaluation. According to Gay (1981), a descriptive research concerns collecting data in order to answer questions concerning the current status of the subjects in the study or test hypothesis. A descriptive research reports the way things are by describing such things as possible behaviour, attitudes, values and characteristics (Gay, 1981). In this study, leadership practice incorporating aspects such as visioning, communication, decision making, reward systems and financial accountability were described. Description data are collected through a questionnaire survey, interview or observation. The questionnaire in this study was meant to solicit information on several aspects of governance and strategic leadership practice of Green Earth Program.

\section{Research Respondents}

The organisation had 42 actively participating registered members at the time of study but only 35 responded to the questionnaire. 35 members constituted $83 \%$ of the active participating members. These members were interviewed during pre and post intervention periods.

\section{Research Tool}

A questionnaire was developed for the purpose of gathering the required information in this study. The questionnaire was an adaptation of the tool developed by Dess and Pickens(1999). Use of the questionnaire gave the respondents a free chance to express their opinions and views and it was capable of giving deeper insight into the five problem areas identified. The questionnaire was divided into five major sections. These were:

- Absence of compelling Strategic Vision and unhealthy competitive conflict: four items were used to address this problem.

- Centralised decision-making : three items were used to address this problem

- Inadequate top-bottom information flow : five items were used to address this problem

- Weak reward system : six items were used to address this problem 
- Weak financial accountability practice: two items were used to address this problem.

Respondents were asked to rate each item on a scale of 0-2 which means:

0 : No response

1: No

2: yes

Questionnaires were filled through emails and others were personally administered by the researcher. Respondents filled the questionnaires by answering YES or NO.

\section{Initial Assessment's Findings}

A questionnaire on leadership and organization learning was administered to 35 respondents in the organization. Questions in the checklist focused on strategic leadership and organisation structure, decision making, information flow, reward system and financial accountability practice. All these areas gave an indication of the need for service improvement as explained by the mean ratings below.

On strategic visioning and organisation structure, four items were considered satisfactory with a rating of 1.43 and on decision making, three items were considered satisfactory with a rating of 1.48. On information flow, five items were considered satisfactorywith a rating of 1.45. On reward system, six items were considered satisfactorywith a rating of 1.37 and on financial accountability practice, two items were considered and both were very satisfactory with a rating of 1.63. A very satisfactory level of leadership practice was observed in this area of leadership practice. Respondents, however, indicated that lack of financial management policies and procedures in the organization created loopholes and gaps that could be exploited by leaders and managers who may not be very accountable in future.

The mean ratings provided evidence that service improvement initiatives were required for this organisation to increase its efficiency level. The ratings did not show that the organization was performing poorly. Rather, they indicated that there was room for service improvement. As some authors have suggested,( Weick and Westley, 1996; Levitt and March, 1988), dramatic impacts on the overall capability of an organization depend on the simultaneous accomplishment of change in many of the aspects of the way the organization functions. That is why the researcher considered several aspects of the organization.

$\begin{array}{ll}\text { Ratings } & \text { Interpretation } \\ 0-0.5 & \text { very poor } \\ 0.5-1.0 & \text { poor } \\ 1.1-1.5 & \text { satisfactory } \\ 1.6-2.0 & \text { very satisfactory }\end{array}$

\section{Statistical Analysis}

An arithmetic mean was used to compute the average scores of the 22 items in the questionnaire. This was done both after pre- assessment and post assessment. The formula used was: 


$$
\begin{gathered}
\text { Mean }=\quad \bar{X}=\frac{\sum_{i=1}^{n} X_{i}}{n} \\
\bar{X}:-\quad \text { arithmetic mean }
\end{gathered}
$$

The $\mathrm{t}$ - test was used to compare the means of the pre-assessment and post- intervention measures. Evaluation scores were addressed for a significant difference at 0.05 Alpha levels.

The formula used was:

$$
\mathbf{t}=\frac{\overline{\mathrm{X}}_{\mathrm{T}}-\overline{\mathrm{X}}_{\mathrm{C}}}{\sqrt{\frac{\operatorname{var}_{\mathrm{T}}}{\mathrm{n}_{\mathrm{T}}}+\frac{\operatorname{var}_{\mathrm{C}}}{\mathrm{n}_{\mathrm{C}}}}}
$$

Furthermore, $\mathrm{p}$ values were computed to measure significant differences for pre and post evaluation.

\section{Findings and Discussions}

The findings presented below relate to pre assessment and post intervention evaluation measurements in the organization under study. 


\section{Profiles of Pre and Post ODI Measurements}

The table below shows the strategic visioning and organization structure profile.

Table 1: Strategic visioning and Organization Structure Profile

\begin{tabular}{|c|c|c|c|c|c|}
\hline NO. & Items & Pre Mean & $\begin{array}{l}\text { Descripti } \\
\text { on }\end{array}$ & $\begin{array}{l}\text { Post } \\
\text { Mean }\end{array}$ & Description \\
\hline & $\begin{array}{l}\text { Strategic Visioning } \\
\text { Organization Structure }\end{array}$ & & & & \\
\hline 1 & $\begin{array}{l}\text { Does the organization have a } \\
\text { compelling vision, mission and } \\
\text { goals? }\end{array}$ & 1.65 & $\begin{array}{l}\text { Very } \\
\text { satisfacto } \\
\text { ry }\end{array}$ & 1.94 & Very satisfactory \\
\hline 2. & $\begin{array}{l}\text { Is the organization's structure in line } \\
\text { with its vision and mission? }\end{array}$ & 1.56 & $\begin{array}{l}\text { Satisfacto } \\
\text { ry }\end{array}$ & 1.94 & Very satisfactory \\
\hline 3. & $\begin{array}{l}\text { Does the structure eliminate } \\
\text { competitive conflict? }\end{array}$ & 1.25 & $\begin{array}{l}\text { Satisfacto } \\
\text { ry }\end{array}$ & 1.94 & Very satisfactory \\
\hline 4. & $\begin{array}{l}\text { Does the organization have } \\
\text { operational guidelines (human and } \\
\text { financial policies)? }\end{array}$ & 1.38 & $\begin{array}{l}\text { Satisfacto } \\
\text { ry }\end{array}$ & 1.94 & Very satisfactory \\
\hline \multirow[t]{2}{*}{5.} & $\begin{array}{l}\text { Does the organization have a clear } \\
\text { and effective monitoring and } \\
\text { evaluation system? }\end{array}$ & 1.30 & $\begin{array}{l}\text { Satisfacto } \\
\text { ry }\end{array}$ & 1.66 & Very satisfactory \\
\hline & Overall mean & 1.43 & $\begin{array}{l}\text { Satisfacto } \\
\text { ry }\end{array}$ & 1.88 & Very satisfactory \\
\hline
\end{tabular}

The table above revealed a very satisfactory level of 1.88 in the area of visionary and strategic leadership practice.

Respondents indicated that there was a great difference between the period before the interventions and the period after the interventions. The organization was able to share its vision and mission and everyone understood the organization's mandate. A strategic plan was also developed which became instrumental in providing the organization with a focus and direction. Kotter(1996) argues that a vision plays a key role in producing useful change by helping to direct, align and inspire actions on the part of large numbers of people. This line of thinking is further supported by the works of Thompson (1997), Daft, R.L and Lengel R.H.(1998). They hold the view that a vision is fundamental in providing direction and motivating the people to act towards realising organizational purpose and goals. As Miles,(1997)has argued, successful corporate transformations share a fundamental attribute: visionary leadership which is the very essence of successful corporate transformation. 
The table below shows the decision making profile.

Table 2: Decision making Profile

\begin{tabular}{|l|l|c|c|c|l|}
\hline & Decision Making & Pre Mean & Description & $\begin{array}{c}\text { Post } \\
\text { Mean }\end{array}$ & Description \\
\hline 6. & $\begin{array}{l}\text { Do staffs at each level have the talent } \\
\text { and skills they need to make decisions } \\
\text { that directly affect their jobs? }\end{array}$ & 1.66 & $\begin{array}{c}\text { Very } \\
\text { satisfactory }\end{array}$ & 1.75 & Very satisfactory \\
\hline 7. & $\begin{array}{l}\text { Is decision making is pushed down to } \\
\text { the lowest possible level at which } \\
\text { competent decisions can be made? }\end{array}$ & 1.36 & satisfactory & 1.94 & Very satisfactory \\
\hline 8. & $\begin{array}{l}\text { Are cross-functional decisions made } \\
\text { through teams and horizontal } \\
\text { organizations? }\end{array}$ & 1.36 & satisfactory & 1.86 & Very satisfactory \\
\hline 9. & $\begin{array}{l}\text { Does the organization encourage and } \\
\text { support bottom-up empowerment? }\end{array}$ & 1.52 & satisfactory & 1.80 & Very satisfactory \\
\hline Overall mean & $\mathbf{1 . 4 8}$ & satisfactory & $\mathbf{1 . 8 4}$ & $\begin{array}{l}\text { Very } \\
\text { satisfactory }\end{array}$ \\
\hline
\end{tabular}

The table above revealed a very satisfactory level of 1.84, of the organisation's decisionmaking process. Respondents indicated that after the interventions, theywere being consulted and asked to contribute ideas that could influence decisions that directly affected their operations. They felt that their involvement in decision- making in matters relating to their work was going to act as a motivator and was to greatly enhance their performance. According to the respondents, the adopted team-based approach to doing things would enhance participative decision making process which would ultimately lead to high performance. Lawler, (1998) argues that effective leadership emphasize the need for employee involvement in decision making. O'Toole(1996) further argues that leadership requires inclusion of followers. This means that followers must fully participate in making decisions that both affect their work and the direction the organization is taking. The table below shows information flow profile.

\section{Table 3: Information Flow (Communication) Profile}

\begin{tabular}{|c|c|c|c|c|c|}
\hline & Information Flow & $\begin{array}{c}\text { Pre } \\
\text { mean }\end{array}$ & Description & $\begin{array}{l}\text { Post } \\
\text { mean }\end{array}$ & Description \\
\hline 10 & $\begin{array}{l}\text { Is sharing of information a widely } \\
\text { accepted practice? }\end{array}$ & 1.44 & Satisfactory & 1.97 & $\begin{array}{l}\text { Very } \\
\text { satisfactory }\end{array}$ \\
\hline 11. & $\begin{array}{l}\text { Does leader have strong listening } \\
\text { skills? }\end{array}$ & 1.55 & Satisfactory & 1.89 & $\begin{array}{l}\text { Very } \\
\text { satisfactory }\end{array}$ \\
\hline 12. & $\begin{array}{l}\text { Does the organization have effective } \\
\text { and efficient mechanisms of } \\
\text { gathering and disseminating } \\
\text { information? }\end{array}$ & 1.44 & Satisfactory & 1.86 & $\begin{array}{l}\text { Very } \\
\text { satisfactory }\end{array}$ \\
\hline 13. & $\begin{array}{l}\text { Do staff and members always know } \\
\text { what is happening in the } \\
\text { organization? }\end{array}$ & 1.40 & Satisfactory & 1.77 & $\begin{array}{l}\text { Very } \\
\text { satisfactory }\end{array}$ \\
\hline \multirow[t]{2}{*}{14.} & $\begin{array}{l}\text { Is information shared across all } \\
\text { organization units? }\end{array}$ & 1.51 & Satisfactory & 1.97 & $\begin{array}{l}\text { Very } \\
\text { satisfactory }\end{array}$ \\
\hline & Overall mean & 1.45 & Satisfactory & 1.89 & $\begin{array}{l}\text { Very } \\
\text { satisfactory }\end{array}$ \\
\hline
\end{tabular}


The overall rating in this category was 1.89 indicating a very satisfactory level of leadership practice. Respondents indicated that for the first time, they were being regularly informed of what the organization was doing, the direction it was taking and areas that they were required to provide their input. Information flow across functional areas was being encouraged. The organization also developed mechanisms of gathering and disseminating information. News briefs through emails were regularly being sent to members. Thompson(1997) argues that effective communication systems are required to share the strategic vision and inform people of priorities and strategies in order to ensure that strategies and tasks are carried out expeditiously. The table below shows the reward system profile.

Table 4: Reward System Profile

\begin{tabular}{|l|l|c|c|c|l|}
\hline & Reward System & Pre mean & Description & Post mean & Description \\
\hline 15. & $\begin{array}{l}\text { Does the organization have } \\
\text { personnel policies that enhance } \\
\text { equitable reward system? }\end{array}$ & 1.18 & satisfactory & 1.74 & Very satisfactory \\
\hline 16. & $\begin{array}{l}\text { Has the organization developed a } \\
\text { pay structure that fortifies employee } \\
\text { morale? }\end{array}$ & 1.61 & $\begin{array}{l}\text { Very } \\
\text { satisfactory }\end{array}$ & 1.43 & Satisfactory \\
\hline 17. & $\begin{array}{l}\text { Are rewards (financial and non- } \\
\text { financial) shared widely throughout } \\
\text { the organization? }\end{array}$ & 1.25 & satisfactory & 1.37 & Satisfactory \\
\hline 18. & $\begin{array}{l}\text { Does the reward system encourage } \\
\text { cross-functional work and } \\
\text { collaboration? }\end{array}$ & 1.29 & satisfactory & 1.60 & Very satisfactory \\
\hline 19. & $\begin{array}{l}\text { Do rewards focus on meeting goals } \\
\text { set? }\end{array}$ & 1.45 & satisfactory & 1.80 & Very satisfactory \\
\hline 20. & $\begin{array}{l}\text { Do rewards encourage systemic } \\
\text { thinking and action? }\end{array}$ & 1.45 & satisfactory & 1.75 & Very satisfactory \\
\hline & Average Mean & $\mathbf{1 . 3 7}$ & satisfactory & $\mathbf{1 . 6 2}$ & Very Satisfactory \\
\hline
\end{tabular}

The table above revealed a very satisfactory level of leadership practice of 1.62 in the area of reward management. Lawler, (1971) submits that reward systems in combination with other features of the organization's design, drives the performance of the organization because it influences critical individual and organizational behaviours. Lawler and Jenkins, (1992) further argue that the pay system is a critical part of any organization's design. Furthermore, pay systems that fit organization's strategies and structures have an important impact on how effective the organization is and on the quality of life that people experience in the organization. 
The table below presents the financial accountability profile which shows the pre test and post test mean ratings.

Table 5: Financial Accountability Practice Profile

\begin{tabular}{|l|l|c|c|c|l|}
\hline & Financial Accountability Practice & Pre Mean & Description & $\begin{array}{c}\text { Post } \\
\text { mean }\end{array}$ & Description \\
\hline 21. & $\begin{array}{l}\text { Is financial accountability practice } \\
\text { guided by policies and procedures? }\end{array}$ & 1.63 & $\begin{array}{c}\text { Very } \\
\text { satisfactory }\end{array}$ & 1.89 & Very satisfactory \\
\hline 22. & $\begin{array}{l}\text { Has the financial accountability } \\
\text { practice been seen as one that } \\
\text { encourages and promotes high levels } \\
\text { of good financial stewardship? }\end{array}$ & 1.62 & $\begin{array}{c}\text { Very } \\
\text { satisfactory }\end{array}$ & 1.95 & Very satisfactory \\
\hline Overall mean & $\mathbf{1 . 6 2 5}$ & $\begin{array}{c}\text { Very } \\
\text { satisfactory }\end{array}$ & $\mathbf{1 . 9 2}$ & Very Satisfactory \\
\hline
\end{tabular}

A very satisfactory level of leadership practice of 1.92 was observed in this area of leadership practice. Respondents were happy with the financial management policies and procedures developed as part of the interventions. Verschool (1995) argues that corporate values and focus on ethics( which are part of good financial accountability practice) do in fact result in superior financial returns. Good financial accountability brings greater success to the bottom line (financial performance).

The post intervention assessment findings reveal that organisation development interventions enhanced the ratings in the organization's leadership and strategic leadership practice. The ratings and the interpretations thereof point to the fact that service improvement had been experienced since all the category areas registered a very satisfactory level of strategic leadership practice.

\section{Table 6: COMPARISON OF PRE AND POST ASSESSMENT DATA}

\begin{tabular}{|c|c|c|c|c|c|c|c|c|c|}
\hline & Improvement issue & $\begin{array}{l}\text { Before } \\
\text { Mean }\end{array}$ & $\begin{array}{l}\text { ODI } \\
\text { Description }\end{array}$ & $\begin{array}{l}\text { After } \\
\text { Mean }\end{array}$ & $\begin{array}{l}\text { ODI } \\
\text { Description }\end{array}$ & $\begin{array}{l}\text { Mean } \\
\text { Difference }\end{array}$ & t-value & $\begin{array}{l}\text { Critical } \\
\text { value }\end{array}$ & $\begin{array}{l}\text { Significance } \\
\text { at } 0.05\end{array}$ \\
\hline 1 & $\begin{array}{l}\text { Visioning and Org. } \\
\text { Structure }\end{array}$ & 1.43 & Satisfactory & 1.88 & Very Satisfactory & 0.45 & 4.089 & 1.682 & Significant \\
\hline 2 & Decision making & 1.48 & Satisfactory & 1.84 & Very Satisfactory & 0.36 & 4.365 & 1.682 & Significant \\
\hline 3 & Information Flow & 1.45 & Satisfactory & 1.89 & Very Satisfactory & 0.44 & 9.170 & 1.682 & Significant \\
\hline 4 & Reward System & 1.37 & Satisfactory & 1.62 & Very Satisfactory & 0.25 & 2.476 & 1.682 & Significant \\
\hline 5 & $\begin{array}{l}\text { Financial } \\
\text { Accountability }\end{array}$ & 1.625 & Satisfactory & 1.92 & Very Satisfactory & $0 . .295$ & 9.700 & 1.682 & Significant \\
\hline & $\begin{array}{l}\text { OVER-ALL } \\
\text { AVERAGE }\end{array}$ & 1.45 & Satisfactory & 1.81 & $\begin{array}{l}\text { Very } \\
\text { Satisfactory }\end{array}$ & 0.36 & 5.142 & 1.682 & Significant \\
\hline
\end{tabular}

This table shows the improvement in the organization's management and leadership practice. The t-values in all the five categories were greater than the critical value and showed significant difference at 0.05 alpha level. The above table also shows that the overall average improvement moved from satisfactory to very satisfactory.

In view of the above, it is evident that the data rejected the null hypothesis. Therefore, there was significant improvement as a result of the Organization Development Interventions administered..The transformation brought about by these interventions was necessary if the organization was to respond adequately to the demands of a quickly developing competitive environment. In order to cope with the ever-changing environment and its constantly increasing competitiveness, new organizations must constantly learn(Senge,1990) and improve themselves (Mohrman and Cummings(1989). 
The figure below graphically shows how the above comparisons appear.
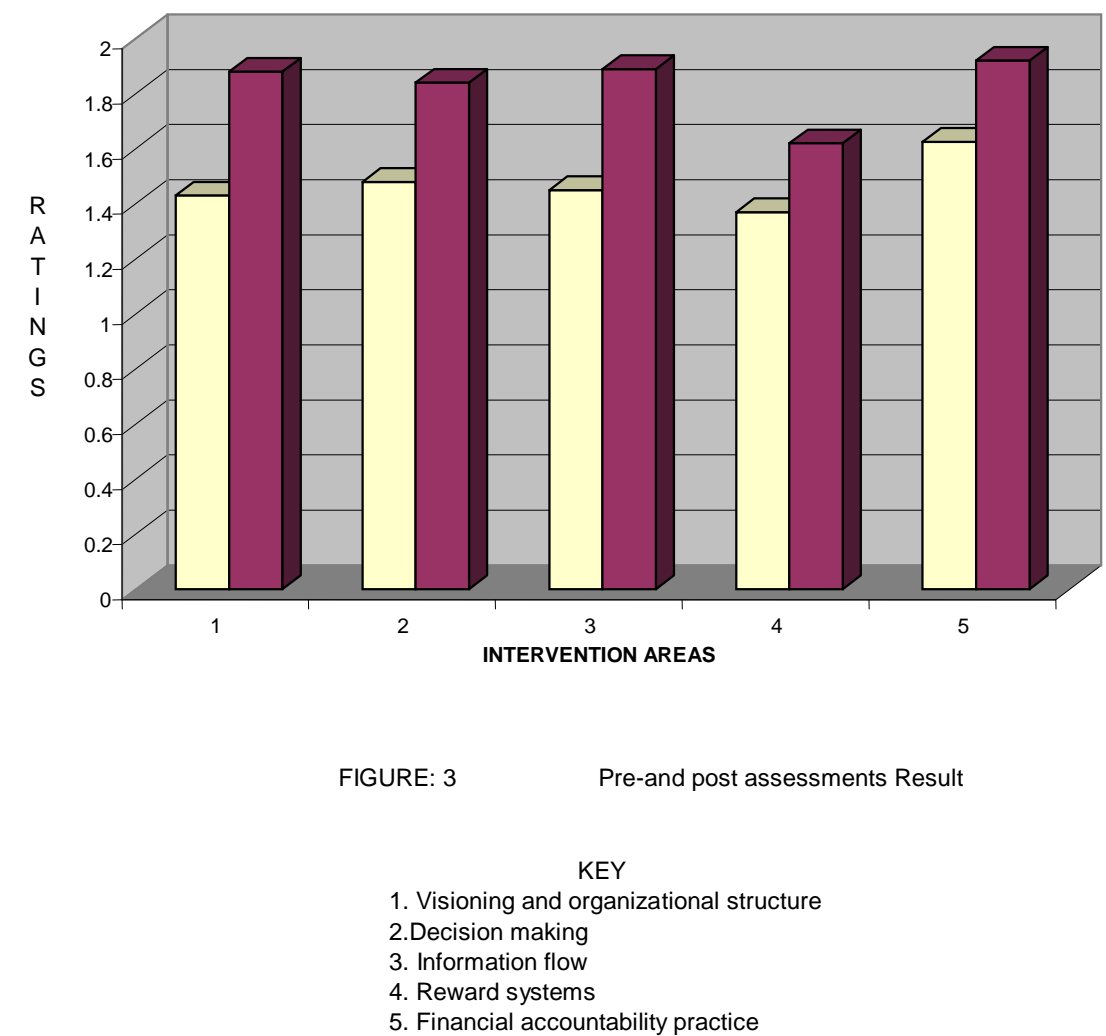

Further tests (t-tests) also produced p-values as a way of ascertaining the conclusions arrived at earlier. The p-values were calculated to confirm whether there were significant differences between pre- assessment and post assessment means. Significant differences would be noticed if $p<0.05$ while there would be no significant difference if $p>0.05$. The results of the $\mathrm{t}$ - test revealed the following according to their respective categories.

On strategic visioning and organization structure, $\mathrm{p}=0.001$ was obtained. This indicates a significant difference between pre- assessment and post assessment ratings.On decision making, $\mathrm{p}=0.005$ was obtained which was less that 0.05 alpha level. This indicates a very significant difference between the ratings obtained during pre- assessment and those obtained after post assessment. On information flow, $\mathrm{p}=0.000$ values were obtained which again were far below the alpha level of 0.05 . This is an indication that there was a very significant difference between pre- assessment and post assessment ratings. Such ratings indicate that the interventions worked extremely well in this category.

On reward systems, $\mathrm{P}=0.033$ value was obtained .These results show that there was a significant difference between pre- assessment rating and post assessment rating. On financial accountability practice, $\mathrm{p}=0.010$ was obtained which was far less than 0.05 alpha level. The results indicate that there was a significant difference between pre- assessment and post assessment data.

Looking at the overall ratings of both pre- assessment and post assessment data, the mean for pre- assessment was 1.45 while the mean for post intervention assessment was 1.81 . The overall $\mathrm{p}$ value was $\mathrm{p}=0.000$. This is a clear indication that there was a very significant difference between data obtained during pre- assessment and data obtained after post 
intervention assessment. Again, all the five categories earlier assessed as problem areas revealed ratings that corresponded with very satisfactory levels of leadership practice in the organization. These findings reveal that the transformation process and the organization development interventions administered to YFC worked very well.

\section{Summary}

The study was done at Green Earth Program. The study focused on assessing and analysing organizational problems and later designing and implementing Organization Development Interventions that would address the identified problems. Interventions to improve the organization' governance and strategic leadership practice were based on Kotter's model (1997) of transforming organizations. The study involved 35 participants during pre assessment and post interventions evaluation. The study focused on five areas namely: compelling vision and organizational structure, decision making, information flow (communication), reward systems and financial accountability practice.

A post intervention evaluation was conducted using the same instrument earlier used during problems identification. The data from the pre intervention assessment and the post intervention evaluation were statistically treated using means.

A t-test was also used to compare the means for significant improvements in the organization's governance and strategic leadership practice. The results of this study found significant improvements in the five problem areas earlier identified. The comparison of the pre and post intervention evaluation showed that the $\mathrm{p}$ - values in all the five categories indicated a significant difference at 0.05 alpha levels. The analysis of the pre and post test intervention data were statistically significant, therefore, the organization development interventions offered were successful.

\section{Conclusion}

The above results have led to the conclusion that the interventions worked since there was a significant difference in the data before and after the interventions. These results have led to the rejection of the hypothesis. The data rejected the hypothesis of no significant difference between the pre and post evaluations and therefore indicates that there was a significant improvement brought about by the interventions

The overarching information in this study is that well identified problems and designing the right interventions and subsequently implementing them will not only transform an organization but also create an organization that is flexible enough to adapt to rapid change in the competitive environment that is agile, creative and daring enough to continuously abandon the old and create the new that builds, nurtures and develops competencies, stock of knowledge and performance capabilities.

\section{References}

Abraham, Zaleznik, (1996) Human Dilemmas of Leadership (New York: Harper \& Row.

Almond Springs (2005) Background Episode B: Shared Vision. Retrieved December 13, 2005 from World Wide Web. http:// christianleaders.org/narrative/svs sharedvision.htm. Anderson, (July-1995) Management Review

Avolio, B.J. , Howell, J.M., Sosik, J. J.( 1999) A Funny Thing Happened on the Way to the Bottom Line: Humor as a Moderator of Leadership Style Effects. Academy of Management Journal. 42(2), 219-220 
Baird J.E. (1977) The Dynamics of Organization Communication. Harper \& Row Publishers. N.Y.

Bennis, B. (1969): Planning for change. ( $2^{\text {nd }}$ ed). (pp 223-245). Lace Press.

Bellehumeur, Robert( 1999), Performance A Moving Target. Optimum: The Journal of Public Sector Management. Vol.29, No. 2/3, 49-55.

Burnes, B. (2000). Managing Change, 3rd edition. (pp123-139). Harlow: Pearson Educational.

Bogler, Ronit and Adam E. Niv.(2001) Organizational Vision: The Other Side of The Coin. He Jounal of Leadership Studies. 8(2). 135- 144.

Carnall, C.A. (2003). Managing Change in Organisations. (pp 23-29). Sydney: Prentice Hall/Pearson Educational.

Daft, R. L. Lengel, R. H. (2005) Vision, Fusion Leadership: Unleaship the Subtle Forces the Change People and Organizations. Barrett, San Francisco, CA.

Duck, J.D. ( November- December, 1993) Managing Change: The Art of Balancing. Havard Business Review, pp. 109- 118.

Gay, R.(1981), Educational Research: Competence for Analysis and Application.Charles E. Mairill Publishing Company. A Bell 7 Howell Company: Toronto.

Harigopal, K. ( 2006), Management of Organizational Change- Leveraging Transformation. $2^{\text {nd }}$ Ed. Sage Publications, New Delhi.

Hill, Charles W.L. Jones, Gareth R,( 1998) Strategic Management: An Integrated Approach, Houghton Mifflin, $4^{\text {th }}$ ed, Boston

Kaplan, Robert and Norton, David (2001) Creating the Strategy- Focused Organization. The Howard Business School Publishing Corporation, Boston.

Kearl, B (1986) Communication and Change in Developing Countries, Honolulu, University of Hawaii.

Kirkpatrick, S.A. , Locke, E.A., (1996) Direct and Indirect Effects of Three Core Charismatic Leadership Components on Performance and Attitudes: Journal of Applied Psychology 8(1), 36-51.

Kolb ( 1970 ) An Organization Development Approach to Consulting. Sloan Management Review.12, pp. 51-65.

Kotter, John P., Leading Change (Harvard Business School Press, 1996).

Kurt Lewin ( 1958 ) Group decision and Social Change in Maccobby, E E Newcomb. T M

Lawler, E.E , Jenkins(1992), The Ultimate Advantage:Creating The High-Involvement Organization.San Francisco: Jossey-Bass

Lawler, E.E.(1971), Pay and Organizational Effectiveness: A psychological View. McGraw-Hill. New York.

Lawler, E.E.(1998), High- Involvement Management: Participative Strategies for Improving Organizational Performance.San Francisco: Jossy- Bass.

Lawler, E. E. , Jenkins, G. D. (1992), Strategic Reward Systems. In M. D. Dunnette and L. M. Hough (eds),Handbook of Industrial and Organizational Psychology. Consulting Psychologists Press: Palo Alto. California.

Ledford,G. E. Jr. , Mohrman, S. A. Mohrman, A. M. , and Lawler, E. E. (1989) The Phenomenon of Large- Scale Change. In A. M. Mohrman, Jr. , and others.LargeScale Organizational Change. Jossy- Bass: San Francisco.

Lerner, (1952) The Passing of a Traditional Society. The Free Press. N.Y.

Lewin, G.W. (1946). Developing Strategies for Change. (pp78-89). Harlow: 
FT/Prentice Hall.

Levitt, B.; March, J. G.(1998) Organizational Learning. Annual Review of Sociology, 14, 319- 320.

Lippit R, Watson J, Westley B. (1958) The Dynamics of Planned Change, Her Court Brace N. Y.

Miles, Robert H.( 1997), Corporate ComeBack, $1^{\text {st }}$ ed. Jossy- Bass Publishers, San Francisco,CA.

Mohrman, S. A. , Lawler E. E. and Galbraith J. R. ( 1998) Tomorrow's Organization: Crafting Winning Capabilities in a Dynamic World. Jossy- Bass Publishers, San Francisco: California.

O'Toole, J. (1996), Leading Change: The Argument For Value-Based Leadership, San Francisco: Jossey- Bass

Seltzer, J., Bass, B. M. (1990) Transformational Leadership: Beyond Initiation and

Consideration; Journal of Management.16(4),693-695.

Senge, P. M.(1990) The Fifth Discipline: The Art and Practice of Learning Organization. Doubleday, New York.

Smith, M.K. (2001) Kurt Lewin: Groups, Experiential Learning and Action Research. The Encyclopaedia of Informal Education, 11(6), 78-89.

Thompson, Robert R., and Gerald R. Thompson. "Organizing for Accounting. Wheaton, III: Harold Shaw, 1991)

Thompson, J. L (1997), Strategic Leadership: Lead With Vision. International Thompson Business Press. London.

Thomas R. Bennett, (1962), The Leader and the Process of Change (New York: Association).

Rhodes, R. (1970), Imperialism and Underdevelopment: A Reader. New York: Monthly Review Press.

Rogers, E. (1976, ED), Communication and Development: Critical Perspectives. Beverly Hills, California: Sage.

Verschool, Curtis (2005) Is The Financial Value in Corporate Values?Strategic Finance Journal. Trinity Western University-Canada.

Weick, K. E. and Westley, F.(1996) Organizational Learning: Affirming an Oxymoron. In S. R. Clegg, C. Hardy and W. R. Nord (eds.), Handbook of Organization Studies. Sage, Thousand Oaks, California. 